๑о. І. Олексяк, С. М. Геряк

Тернопільський національний медичний університет ілені I. Я. Горбачевсъкого МОЗ України

\title{
ОСОБЛИВОСТІ РОЗВИТКУ АКУШЕРСЬКИХ УСКЛАДНЕНЬ У ВАГІТНИХ ІЗ ХРОНІЧНИМИ ОБСТРУКТИВНИМИ ЗАХВОРЮВАННЯМИ ЛЕГЕНЬ (ОГЛЯД ЛІТЕРАТУРИ ТА ВЛАСНІ ДАНІ)
}

\begin{abstract}
Мета дослідження - вивчення та аналіз фракторів, що впливають на виникнення акушерських ускладнень у вагітних із хронічними обструктивними захворюваннями легень.

Матеріали та методи. У цьому огляді літератури використовували бібліосемантичний та аналітичний методи.

Результати дослідження та їх обговорення. Наявність хронічних обструктивних захворювань супроводжується активацією вільнорадикальних процесів у легенях. Вільні радикали мають властивість модисрікувати білки, ліпіди, нуклеїнові кислоти, що в результаті стає причиною ендотеліальної диссрункції. У хворих із хронічними обструктивними захворюваннями легень виявлено зв'язок між вираженням ендотеліальної диссункції, пероксидного окиснення ліпідів та активністю системи антиоксидантного захисту. Ендотеліальну диссрункцію на даний час вважають одним з основних патогенетичних механізмів, що лежить в основі розвитку таких акушерських ускладнень, як передчасні пологи, плацентарна дисфункція, синдром затримки росту плода, гестози та ін. Проведений ретроспективний аналіз 120 історій показав, що у вагітних із хронічними обструктивними захворюваннями легень розвиваються такі акушерські ускладнення, як диссункція плаценти в 65,0 \%, загроза передчасних пологів у 55,8 \%, гестози в 38,3 \%, синдром затримки росту плода у 16,6 \%, передчасний розрив навколоплідних оболонок у 15,0 \%, дистрес плода в 12,5\%.

Висновок. Враховуючи значну поширеність акушерських ускладнень у вагітних із хронічними обструктивними захворюваннями легень, ця проблема $€$ актуальною і вимагає поглибленого вивчення та аналізу для розробки адекватних програм прогнозування, діагностики ускладнень та ведення вагітних із хронічними обструктивними захворюваннями легень.

Ключові слова: хронічні обструктивні захворювання легень; ендотеліальна диссрункція; ускладнення вагітності; оксидативний стрес; кислотно-лужний баланс.
\end{abstract}

ОСОБЕННОСТИ РАЗВИТИЯ АКУШЕРСКИХ ОСЛОЖНЕНИЙ У БЕРЕМЕННЫХ С ХРОНИЧЕСКИМИ ОБСТРУКТИВНЫМИ ЗАБОЛЕВАНИЯМИ ЛЕГКИХ (ОБЗОР ЛИТЕРАТУРЫ И СОБСТВЕННЫЕ ДАННЫЕ)

Цель исследования - изучение и анализ факторов, влияющих на возникновение акушерских осложнений у беременных с хроническими обструктивными заболеваниями легких.

Материалы и методы. В данном обзоре литературы использовали библиосемантический и аналитический методы.

Результаты исследования и их обсуждение. Наличие хронических обструктивных заболеваний сопровождается активацией свободнорадикальных процессов в легких. Свободные радикалы имеют свойство модисицировать белки, липиды, нуклеиновые кислоты, что в результате становится причиной эндотелиальной дисфункции. У больных с хроническими обструктивными заболеваниями легких была обнаружена связь между выраженностью эндотелиальной диссункции, перекисного окисления липидов и активностью системы антиоксидантной защиты. Эндотелиальная диссункция в настоящее время считается одним из основных патогенетических механизмов, лежащих в основе развития таких акушерских осложнений, как преждевременные роды, плацентарная диссункция, синдром задержки роста плода, гестозы и др. Проведенный ретроспективный анализ 120 историй показал, что у беременных с хроническими обструктивными заболеваниями легких развиваются следующие акушерские осложнения: диссрункция плаценты у 65,0 \%, угроза преждевременных родов у 55,8 \%, гестозы у 38,3 \%, синдром задержки развития плода у 16,6 \%, преждевременный разрыв околоплодных оболочек у 15,0 \%, дистресс плода у 12,5 \%.

Вывод. Учитывая значительную распространенность акушерских осложнений у беременных с хроническими обструктивными заболеваниями легких, данная проблема является актуальной и требует углубленного изучения и анализа для разработки адекватных программ прогнозирования, диагностики осложнений и ведения беременных с хроническими обструктивными заболеваниями легких.

Ключевые слова: хронические обструктивные заболевания легких; эндотелиальная диссункция; осложнения беременности; оксидативный стресс; кислотно-щелочной баланс.

THE FEATURES OF OBSTETRIC COMPLICATIONS DEVELOPMENT IN PREGNANT WOMEN WITH CHRONIC OBSTRUCTIVE PULMONARY DISEASES (THE LITERATURE REVIEW AND OWN RESEARCH)

The problem of chronic obstructive pulmonary diseases in pregnant women increasingly has become relevant in obstetrics. The body's oxygen needs increasing by 15-20 \% during physiological pregnancy, and therefore, in the presence of chronic pathology, this can cause decompensation of the disease as well as change the clinical course of pregnancy. Thus, the combination of chronic obstructive pulmonary disease with pregnancy can cause unpredictable complications for both mother and fetus.

The aim of the study - to determine and analyze the factors that affecting occurrence on the obstetric complications in pregnant women with chronic obstructive pulmonary diseases.

Materials and Methods. Bibliosemantic and analytical methods were used in this literature review.

Results and Discussion. A connection between the severity of endothelial dysfunction, lipid peroxidation, and the activity of the antioxidant defense system in pregnant women with chronic obstructive pulmonary disease, was found. The chronic 
obstructive diseases are accompanied by the activation of free radical processes in the lungs. Free radicals have the ability to modify proteins, lipids, nucleic acids, which cause endothelial dysfunction. Endothelial dysfunction is currently considered one of the main pathogenetic mechanisms underlying the development of such obstetric complications as premature birth, placental dysfunction, intrauterine growth retardation, preeclampsia and others. A retrospective analysis of 120 histories of pregnant women with chronic obstructive pulmonary diseases revealed that the following obstetric complications had been developed: placental dysfunction in $65.0 \%$, premature birth in $55.8 \%$, preeclampsia in $38.3 \%$, intrauterine growth retardation in $16.6 \%$, premature ruptured membrane in $15 \%$, fetal distress in $12.5 \%$.

Conclusion. Chronic obstructive pulmonary diseases in pregnant women are accompanied with endothelial dysfunction, lipid peroxidation violation and increascent oxidative stress that need to develop an adequate programs for prediction of the obstetrics and perinatal complications in pregnant women with chronic obstructive pulmonary diseases.

Key words: chronic obstructive pulmonary diseases; endothelial dysfunction; pregnancy complications; oxidative stress; acid-base balance.

ВСТУП. Хронічне обструктивне захворювання легень (ХОЗЛ) на даний час залишається найбільш непередбачуваним захворюванням легеневої системи, оскільки характеризується повільним розвитком, персистуючим обмеженням прохідності дихальних шляхів, різноманітністю клінічних проявів та тригерів, які негативно впливають та погіршують перебіг захворювання. Попередити дану патологію та її ускладнення можна лише за умови профрілактики фракторів ризику, що погіршують якість життя хворих та, навіть, можуть призвести до інвалідизації, шляхом відмови від тютюнокуріння, раннього призначення постійної базисної фрармакотерапії, вчасного лікування загострень [1, 2].

МЕТА ДОСЛІДЖЕННЯ - вивчення та аналіз фракторів, що впливають на виникнення акушерських ускладнень у вагітних із хронічними обструктивними захворюваннями легень.

МАТЕРІАЛИ ТА МЕТОДИ. У цьомУ огляді літератури використовували бібліосемантичний та аналітичний методи.

Частка ХОЗЛ, як однієї з провідних причин інвалідизації та смертності, постійно збільшується. Так, у 1990 р. ХОЗЛ були на 6-му місці серед причин смертності, до 2020 р. перемістилися на 3-тє місце [3-5]. Серед усіх пацієнтів із ХОЗЛ тільки у половини встановлений клінічний діагноз, а 20 \% припадає на людей, які ніколи не зловживали курінням. При цьому, суспільство мало знає про цю проблему, а за витратами на наукові дослідження ХОЗЛ знаходиться на 13-му місці $[1,6,7]$.

У суспільстві поширена думка, що ХОЗЛ - це захворювання курців чоловічої статі старшої вікової категорії. Останні доказові дані свідчать про швидке поширення та високу смертність від ХОЗЛ і серед жінок [8, 9]. За даними ВОО3, ускладнення хронічних обструктивних захворювань легень у жінок $є$ причиною смертності в 1,5 раза більше, ніж від раку молочної залози та раку легень [10]. Причини такого явища різноманітні: куріння, яке за останні десятиліття значно поширилося серед жінок, продукти згоряння біоорганічного палива, пасивне куріння, гірша переносимість тютюну, на відміну від чоловіків, тяжчий перебіг на тлі порушень гормонального фону в жінок. Важлива роль належить і соціально-економічному статусу: чим він нижчий, тим вищі шанси захворіти [1].

На думку експертів Європейського респіраторного товариства (ERS 2013), від 9 до 30 \% хворих, які страждають від ХОЗЛ, не підозрюють про наявність у них захворювання, оскільки хворобу зазвичай не діагностують до розвитку клінічно виражених стадій захворювання, i лише у 25 \% випадків діагностують своєчасно, а близько 65 \% пацієнтів не отримують адекватної терапії [7].

Особливо чутливу категорію завжди становили вагітні жінки. Властивість дихальної системи забезпечувати повноцінний газообмін вкрай необхідна під час вагітності, оскільки використання кисню в цей період зростає на 15-20 \%. Чутливість дихального центру до вуглекислого газу підвищується, що зумовлено дією прогестерону [11]. Ці потреби задовольняються за рахунок підвищення навантаження на дихальну систему шляхом структурних та фрункціональних змін, а при наявності хронічної патології дихальної системи недостатня оксигенація може як спричинити декомпенсацію захворювання, так і змінити клінічний перебіг вагітності.

ХОЗЛ належить до класичного прикладу взаємодії генів та навколишнього середовища. Найбільш вивченим генетичним фрактором ризику розвитку хронічного обструктивного захворювання легень $€$ десріцит $\alpha_{1}$ антитрипсину. Відповідно до даних дослідження Тhe Global Burden of Disease study (2017), активне та пасивне куріння, забруднення твердих часток навколишнього середовища та атмосферного повітря, професійна діяльність людини, тверде паливо, свинець належать до поширених причин ХОЗЛ. Серед вагомих анатомічних та функціональних змін дихальної системи під час вагітності можна виділити: піднімання діафррагми до 4 см, зниження загальної ємності легень, функціональної залишкової ємності легень (ФЗЄЛ), залишкового об'єму легень, збільшення хвилинної вентиляції, зменшення дифузних властивостей легень на $15 \%$, зростання споживання кисню, гіперсекреція і набряк слизової оболонки дихальних шляхів (переважно в третьому триместрі). Водночас адаптація дихальної системи вагітної також відбувається за рахунок збільшення легеневої вентиляції на 40 \%, через це дихальний об'єм зростає від 500 до 700 мл. В організмі жінки під час вагітності відбувається перебудова кістково-м'язового каркаса грудної клітки, збільшення передньо-заднього і транслатерального розміру грудної клітки. У результаті розширюються міжреберні проміжки, зберігається черевний тип дихання (особливо в положенні на спині), що забезпечує достатню екскурсію діадррагми. Незважаючи на піднімання діафрагми, підвищення внутрішньочеревного тиску та збільшення дихального об'єму, критичної зміни легеневих об'ємів не відбувається [12]. Оскільки життєва ємність легень та частота дихання при цьому не змінюються, як наслідок, відбувається зниження фрункціональної залишкової ємності, остаточного об'єму і, відповідно, форсованого об'єму видиху за 1 с 
$[13,14]$. У зв'язку з цим, вагітні з хронічним обструктивним захворюванням легень є особливою категорією пацієнтів, які потребують посиленого спостереження та перебувають в зоні ризику не лише загострень супутньої патології бронхолегеневої системи під час вагітності, а й розвитку перинатальних та акушерських ускладнень.

Також існують дані про зміни показників функції зовнішнього дихання у вагітних із ХОЗЛ, що зумовлює ще більше зниження сатурації та погіршення перебігу вагітності, особливо при наявності супутньої патології легень. Ця теорія ґрунтується на тому, що слизова оболонка дихальних шляхів набрякає в результаті гормональноопосередкованого капілярного застою [15]. У цьому аспекті, окрім стану матері, залишається відкритим питання внутрішньоутробної адаптації плода, який на етапі свого розвитку потребує більшої оксигенації.

Зі збільшенням терміну вагітності зростання потреби в насиченості киснем фетального гемоглобіну викликає збільшення частоти серцевих скорочень матері на 1020 \% та серцевого викиду на 30-60 \% при максимальній вазодилатації, що сприяє збільшенню кровопостачання матки в 10 разів, а різке підвищення перфузії органів плода може стати причиною внутрішньоутробного ушкодження. Таким чином, дисбаланс рівнів $\mathrm{PaO}_{2}$ i $\mathrm{PaCO}_{2} \mathrm{y}$ вагітних жінок може бути причиною тяжкої респіраторної диссункції та порушення споживання кисню плодом [16]

У третьому триместрі вагітності у жінок за рахунок високого стояння діафррагми відбувається поглиблення легенево-діафрагмальних синусів. У результаті в 50 \% жінок виникає задишка, тому навіть легкі фрорми легеневої патології можуть провокувати хронічну гіпоксію у матері. Перебіг бронхіальної астми під час вагітності часто недооцінюють за рахунок змін функцій зовнішнього дихання (зниження ОФВ 1 , залишкового об'єму легень, співвідношення ОФВ 1 ЖЄЛ, форсованої життєвої ємності легень, видиху до аналогічного параметра при вдиху, збільшення бронхіального опору) та часто інтерпретують у вагітних як фрізіологічний [16]. За рахунок збільшення об'єму плазми зростає частота серцевих скорочень у вагітної та ударного об'єму серця. Внаслідок цього при патології дихальної системи раптово може розвинутися легенева гіпертензія, збільшитися навантаження на праві відділи серця та може спостерігатися симптоматика легеневосерцевої недостатності [16].

Порушується і кислотно-лужний баланс. У першому триместрі вагітності розвивається хронічний компенсований алкалоз: відбувається піднімання $\mathrm{PaO}_{2}$ до 104108 мм рт. ст., а РаСО 2 знижується до рівня 27-32 мм рт. ст., проте внаслідок підвищеної екскреції бікарбонату нирками рН артеріальної крові при орізіологічному перебігу вагітності не змінюється.

За даними дослідження О. Б. Приходько, Е. Б. Романцова, А. Ф. Бабцева (2007), у 50 \% вагітних спостерігали порушення адаптації дихальної системи при хронічних обструктивних захворюваннях легень [17]. Незважаючи на фрізіологічну адаптацію дихальної системи матері, організм дитини гірше реагує на кисневе голодування. Оскільки обмін кисню між матір'ю та плодом відбувається пасивно, $\mathrm{pO}_{2}$ плода ніколи не може бути більшим за материнське. Як результат, погіршується оксигенація органів плода, що спричиняє гіпоксію та затримку його внутрішньоутробного росту.
Одним з найскладніших завдань у веденні вагітних із екстрагенітальною патологією залишається адекватне прогнозування та попередження загострень основного захворювання у матері та розвитку акушерських ускладнень, що часто погіршують перебіг пологів та перинатальні наслідки. У контексті хронічного обструктивного захворювання легень такий негативний вплив являє собою хронічне запалення. Bafadhel M. et al. (2011) виділили декілька френотипів загострення ХОЗЛ, що ґрунтується на виявленні специфічних біомаркерів $[18,19]$. У ході дослідження виявлено загострення, асоційоване з бактеріями (35\%), що характеризується збільшенням нейтросрілів у мокротинні та периферичній крові. Біомаркерами для цього типу $є$ рівень IL- $\beta$ у мокротинні та С-реактивний білок. Наступний тип - це загострення, асоційоване з вірусами (35\%), для якого специсрічним біомаркером $€$ хемокін CXCL10 у сироватці крові. Специсрічним маркером для еозинофрільного загострення (24\%) $€$ рівень еозинофрілії в периферичній крові. Четвертий френотип дослідники віднесли до слабозапального типу (11 \%) [20]. У контексті цього дослідження рано говорити про широке розповсюдження представленої класифрікації, але цілком реально передбачити виникнення загострень, що для вагітних жінок може мати вирішальне значення для перебігу гестації.

Основну роль у виникненні ускладнень вагітності при хронічному обструктивному захворюванні легень відводять розвитку гіпоксичного ураження, яке можна поділити на три стадії. Компенсована стадія дихальної недостатності проявляється лише наявністю респіраторної гіпоксії. Субкомпенсована стадія характеризується приєднанням циркуляторної гіпоксії, що призводить до ураження тканинного дихання. При декомпенсованій стадії в організмі розвивається респіраторна, циркуляторна та вторинна тканинна гіпоксія, що значно погіршує перебіг основного захворювання та викликає порушення стану плода. Обтяжливими фракторами респіраторної гіпоксії у вагітних із хронічними обструктивними захворюваннями легень можуть бути довготривалі запальні процеси в бронхіальному дереві, що супроводжуються швидким зменшенням життєвої ємності легень (ЖЄЛ), альвеолярної вентиляції, дисузної поверхні легень та, як наслідок, прогресуючим розвитком дихальної недостатності [21].

У патогенезі ХОЗЛ, що ґрунтується на хронічному запаленні повітроносних шляхів, основну роль відводять паренхімі та судинам легень, дисбалансу системи протеаз/антипротеаз у легенях і оксидативному стресу [22].

Одну з провідних ролей у появі перинатальних ускладнень та прогресуванні хронічного обструктивного захворювання легень під час вагітності відіграють лімфоцити. У підслизовій оболонці дихальних шляхів і в периферичній крові збільшується кількість CD8+-лімфроцитів, які мають цитотоксичну пам'ять, що стає можливим завдяки зменшенню ЖЄЛ та зниженню циркуляції повітря в нижніх відділах легень під час вагітності [22]. Також збільшуються допоміжні CD4+-клітини, що відповідають за вироблення прозапальних цитокінів. Majori M. et al. (1999) показали, що особливо збільшується кількість клітин, що продукують у-інтерсрерон [23]. Декілька досліджень показали зв'язок між ХОЗЛ та системним запаленням низького ступеня [22]. Метааналіз, проведений Gan WQ et al. (2004), показав, що пацієнти зі стабільним перебігом 
ХОЗЛ мають високий рівень лейкоцитів, СРБ та фрібриногену, деяких цитокінів (IL-6) та TNF- $\alpha$ [24].

Під час вагітності, особливо у третьому триместрі, при загостренні хронічного обструктивного захворювання легень спостерігають збільшення концентрації циркулюючих імунних комплексів та ендотоксинів, які регулюють проникність гематоплацентарного бар'єра і тонус судин [25]. Внаслідок цього розвивається хронічне порушення фетоплацентарного кровообігу у вагітної та церебрального кровообігу у новонародженого [15]. Спостерігають порушення регуляції Т-клітинного імунітету і розвиток диссрункції судин ендотелію жінок у першому триместрі гестації за рахунок зниження молекул CD4 і CD8, які беруть участь у підтриманні запальної реакції [26]. Відповідно, відсутність адекватної відповіді на запальний процес в легенях погіршує перебіг як хронічного обструктивного захворювання легень, так і вагітності.

Загалом захворювання органів дихання $€$ досить частою причиною ускладнень вагітності (від 5 до $9 \%$ ), оскільки загострення ХОЗЛ складає 10 \% випадків серед усієї екстрагенітальної патології та вимагає негайної госпіталізації таких вагітних [27]. Найчастіше під час вагітності спостерігають бронхіальну астму, бронхіти та пневмонії. Вагітні жінки, які страждають від бронхіальної астми, мають вищий ризик несприятливого перебігу вагітності та пологів, тому в рекомендаціях GINA (2016) ХОЗЛ належить до фракторів ризику ускладнень вагітності [28]. У дослідженнях Мерфі (2011) виявлено, що найчастіше бронхіальна астма ускладнюється токсикозом (до 37 \%), пізнім гестозом (до $43 \%$ ), загрозою переривання вагітності (до 26 \%), плацентарною дисфункцією (до 29 \%) [29].

До цього часу науковці та лікарі не дійшли остаточної думки щодо діапазону виникнення загострень ХОЗЛ протягом вагітності, проте вважають, що більш небезпечний період - це II і III триместри вагітності з піком загострень у 22-34 тижні [30, 31]. Також, за даними Murphy and Gibson (2011), до ризиків виникнення ускладнень ХОЗЛ під час вагітності належать: несвоєчасно призначене лікування, недостатня доза кортикостероїдної терапії, ожиріння, метаболічні порушення [29].

Наявність ХОЗЛ супроводжується активацією вільнорадикальних процесів у легенях. Вільні радикали мають властивість модифікувати білки, ліпіди, нуклеїнові кислоти, що в результаті стає причиною ендотеліальної диссрункції. У хворих із ХОЗЛ виявлено зв'язок між вираженням ендотеліальної дисфункції, пероксидного окиснення ліпідів та активністю системи антиоксидантного захисту [32].

Несприятливий вплив на плід у вагітних із ХОЗЛ відбувається в тому числі й за рахунок збільшення оксидативного стресу. Кліфтон та ін. (2005) експериментально вперше довели підвищення оксидативного стресу у вагітних із бронхіальною астмою. Плаценти вагітних 3 астмою мали більш високий рівень маркерів пероксидного окиснення ліпідів і маркерів оксидативного стресу порівняно $з$ плацентами жінок без астми [33]. Пізніше підвищена експресія мРНК плацентарних цитокінів також була виявлена в плацентах вагітних, які хворіли на ХОЗЛ легкого та середнього ступенів тяжкості, порівняно з плацентами жінок без патології [34].

Ендотеліальну диссрункцію на даний час вважають одним з основних патогенетичних механізмів, що лежить в основі розвитку таких акушерських ускладнень, як передчасні пологи, плацентарна дисфункція, синдром затримки росту плода, гестози тощо [35]. За даними дослідження О. Ю. Іванова та ін. (2010), висока частота обтяженого акушерського анамнезу (71 \%) підвищує ризик негативного впливу судинного фактора на розвиток комплексу «мати - плацента - плід» [36]. Серед екстрагенітальної патології, що сприяє виникненню порушень судинної стінки, не останнє місце належить хронічним обструктивним захворюванням легень. При бронхіальній астмі та інших хронічних обструктивних захворюваннях легень ендотеліальна диссрункція погіршує наростаючу дихальну недостатність, гіпоксемію та гіпоксію тканин [37].

Тема функціональної активності ендотелію вперше була озвучена в 1980 p. R. F. Furchgott та J. V. Zawadzki [38]. Завдяки виявленню багатофункціональності ендотелію, його з того часу прийнято вважати найважливішою ендокринною залозою в організмі [39]. Цілісний ендотелій бере участь в регуляції гемореологічних властивостей крові. Це допомагає забезпечувати нормальне функціонування фетоплацентарного комплексу. До однієї 3 базових фрункцій ендотелію належить здатність виділяти вазоактивні агенти. Основний з них - це оксид азоту (NO), який $є$ важливим компонентом для сприятливого перебігу вагітності. Відомо, що рівень оксиду азоту під час вагітності зростає, оскільки в організмі жінки відбувається перебудова захисних систем у відповідь на посилення фрізіологічного стресу. В крові підвищується кількість нейтрофрілів та порушується система нейтрофрільного апоптозу. Ця системна запальна реакція супроводжується виробленням активних фрорм кисню за рахунок респіраторного вибуху в нейтросрілах [25], при цьому відповідальна за вироблення активних форм кисню плацента як головний регулюючий орган вагітності [48].

Водночас активація оксидативних процесів $€$ необхідною умовою для нормального фрункціонування клітин та нормальної відповіді редокс-системи під час вагітності [40-43]. Адекватне вироблення NO допомагає забезпечити достатній кровообіг, живлення та оксигенацію плода. За вироблення оксиду азоту відповідає NO-синтазна система, яка бере участь в плацентарному кровообігу під час вагітності [44]. Недостатнє вироблення NO-синтази ендотелієм призводить до хронічної дисфункції, яка, за даними дослідження В. Л. Зверко, Н. Е. Максимович, Т. С. Милош (2010), може бути причиною загрози передчасних пологів. Заявлені порушення супроводжуються зниженням перфузії тканин, погіршенням транспорту кисню в тканинах, розвитком гіпоксії та метаболічного ацидозу не лише в матері, а й у плода [44].

Також важлива роль в патогенезі ендотеліальної дисорункції належить ендотеліну-1 (ЕТ-1) - великому біциклічному поліпептиду, що синтезується в бронхіальному епітелії, ендотелії та альвеолярних макрофрагах. При гіпоксемії, загостренні хронічного обструктивного захворювання легень відбувається збільшення в крові ендотеліну-1 [45]. Тому серед ускладнень хронічних обструктивних захворювань ризик виникнення прееклампсії збільшується не менше як у 1,5 раза [16].

Одним із сракторів ризику розвитку прееклампсії $\epsilon$ і попередньо високий рівень фрактора некрозу пухлин альфра. На фроні загострень ХОЗЛ відбувається підвищення рівня в крові таких жінок прозапальних цитокінів 
(IL-1, IL-6), ендотеліну-1, фрактора активації тромбоцитів, фрактора Віллебранда, продуктів пероксидного окиснення ліпідів, загального $\lg$ Е та зниження рівня простацикліну, а підвищення рівня IL-1а можна трактувати як маркер ушкодження ендотеліоцитів, що підтверджує теорію судинного ураження при прееклампсії. Порушення балансу судинної регуляції причиною підвищеної активації ендотелію, що в комплексі зі складними імунними порушеннями в організмі вагітної жінки з ХОЗЛ (ріст в периферичній кров молекул адгезії sVCAM-1 і sICAM-1) стає причиною підвищеної частоти виникнення прееклампсії [46].

Під час дії інфрекційних чинників на фоні загострення хронічних обструктивних захворювань легень посилюється вироблення інтерферону-у, що стає причиною цитотоксичних реакцій та призводить до передчасного старіння плаценти. За рахунок порушень компенсаторних механізмів на молекулярному, клітинному та тканинному рівнях формується хронічна плацентарна дисорункція $[47,58]$.

Згідно з даними А. І. Синопальникова та ін. (2017), позалікарняні пневмонії, які розвиваються на фоні ураження легень, стають причиною таких перинатальних ускладнень, як загроза передчасних пологів (68,4 \%), дисфункція плаценти (60,5 \%), внутрішньоутробна гіпоксія плода (44,7\%), порушення матково-плацентарного кровообігу (36,8 \%). Також ймовірність виникнення ускладнень залежить від терміну гестації, коли було перенесене захворювання (у першому триместрі - 31,6 \%, в другому $23,7 \%$, у третьому - 21,1\%) $[49,50]$.

Метааналіз перинатальних наслідків у вагітних із бронхіальною астмою V. E. Murphy (2011) показав достовірне збільшення ризику передчасних пологів у вагітних із неконтрольованим перебігом бронхіальної астми. За умов гіпоксії, яка є основною ознакою хронічних обструктивних захворювань легень, в матці запускається специфічний механізм, що стає причиною гіперреактивності гладкої мускулатури [29].

Ризики для плода також складають велику частину ускладнень у вагітних із ХОЗЛ. Так, у когортному дослідженні М. С. Breton (2010), що включало 13100 хворих на бронхіальну астму і 28042 жінок без бронхіальної астми, виявили збільшений ризик перинатальної смертності на $34 \%$ [38]. Blais and Forget у 2008 р. дійшли висновку, що загострення бронхіальної астми під час першого триместру може бути причиною уроджених вад розвитку дитини, зокрема патології серцево-судинної та опорно-рухової систем, які асоціюються з прийманням таблетованих глюкокортикостероїдів [51].

Метааналіз (V. E. Murphy, 2011) показав збільшення на 24 \% частоти випадків незрілості плода щодо терміну гестації і, відповідно, при некоректній терапії бронхіальної астми - нижчий ризик народження дитини масою тіла більше 3 кг [29].

Горіков І. Н. та ін. (2010) виявили, що у вагітних із хронічним бронхітом були клінічно діагностовані ознаки внутрішньоутробної затримки росту, а новонароджені мали нижчі антропометричні показники. Також у період гестації була відзначена тенденція до збільшення судинного опору в середній мозковій артерії (СМА), особливо у дітей з церебральною ішемією [52].

Основними напрямками профрілактики ускладнень хронічного обструктивного захворювання легень зали- шаються відмова від активного куріння, вейпінгу та мінімізація пасивного куріння, зменшення впливу шкідливих чинників навколишнього середовища, вчасна діагностика та лікування основного та супутніх захворювань [1].

Для терапевтичного контролю хронічних обструктивних захворювань легень використовують інгаляційні глюкокортикостероїди, короткодіючі $\beta_{2}$-агоністи, пероральні та внутрішньовенні теофіліни. Вагітність не може бути причиною відмови від таблетованих глюкокортикостероїдів, хоча і доведено, що ендогенні глюкокортикостероїди можуть бути причиною внутрішньоутробної затримки росту плода [29]. Як альтернативну терапію можна застосовувати антилейкотрієнові препарати, але лише для категорії жінок, які досягли покращення симптомів до вагітності порівняно з ефективністю препаратів першої лінії [53].

Для лікування хронічного обструктивного захворювання легень першою лінією препаратів є бронходилататори. При наявності вираженого запального компонента необхідно використовувати комбіновані препарати з глюкокортикостероїдами, що допоможе запобігти виникненню ускладнень [53].

РЕЗУЛЬТАТИ ДОСЛІДЖЕНЬ ТА ЇХ ОБГОВОРЕННЯ. Проаналізовано близько 120 історій вагітності та пологів у жінок із хронічними обструктивними захворюваннями легень різного ступеня тяжкості, які перебували на лікуванні у Тернопільському обласному клінічному перинатальному центрі «Мати і дитина», за період 2010-2020 рр. Усі історії містили дані про перебіг вагітності та пологів. У вагітних із ХОЗЛ виявлено протягом вагітності такі захворювання легеневої системи, як бронхіти - 82 (68,3 \%), бронхіальна астма - 18 (15,0\%), бронхоектатична хвороба - 7 (5,8 \%), пневмонії - 20 (16,6 \%). Серед акушерських ускладнень найчастіше спостерігають диссрункцію плаценти - 78 (65,0 \%), загрозу передчасних пологів - 67 $(55,8 \%)$, гестози - 46 (38,3\%), синдром затримки росту плода - 20 (16,6 \%), передчасний розрив навколоплідних оболонок - 18 (15,0 \%), дистрес плода - 15 (12,5\%). Постнатально в 33,3 \% (40 новонароджених) була діагностована мала маса тіла, що не відповідала терміну гестації. У 21,6 \% спостерігали два і більше акушерських ускладнення.

Провідне місце серед акушерських ускладнень займає дисфункція плаценти, що при відсутності адекватної терапії може призводити до значного порушення гемодинамічних показників плода. Встановлено, що в період 26-28 та 34-36 тижнів гестації показник індексу резистентності в маткових артеріях статистично більш виражений у вагітних із ХОЗЛ та плацентарною дисфункцією порівняно зі здоровими вагітними [54].

Висновок. Вчасна діагностика, попередження та лікування акушерських ускладнень у вагітних із хронічними обструктивними захворюваннями легень $€$ важливим напрямком дослідження, що потребує розроблення критеріїв прогнозування, діагностики, програм акушерського супроводу та методу розродження, що допоможе в майбутньому зменшити частоту ускладненого перебігу вагітності та пологів.

ПЕРСПЕКТИВИ ПОДАЛЬШИХ ДОСЛІДЖЕНЬ. Хронічні обструктивні захворювання легень супроводжуються ендотеліальною дисфрункцією, пероксидним окисненням ліпідів та наростаючим оксидативним 
стресом. Це вимагає подальшої розробки адекватних програм прогнозування акушерських та перинатальних ускладнень у вагітних із хронічними обструктивними захворюваннями легень.

\section{СПИСОК ЛІТЕРАТУРИ}

1. Global Initiative for Chronic Obstructive Lung Disease (GOLD) 2017.

2. Blais L. Asthma exacerbations during the first trimester of pregnancy and the risk of congenital malformations among asthmatic women / L. Blais, A. Forget // J. Allergy Clin. Immunol. - 2008. - Vol. 121 (6). - P. 1379-1384.

3. Global and regional trends in COPD mortality, 1990-2010/ P. G. Burney, J. Patel, R. Newson [et al.] // Eur. Respir. J. - 2015. - Vol. 45 (5). - P. 1239-1247.

4. Gender and chronic obstructive pulmonary disease: why it matters / M. K. Han, D. Postma, D. M. Mannino [et al.] // Am. J. Respir. Crit. Care Med. - 2007. - Vol. 176 (12). - P. 1179-1184.

5. Years lived with disability (YLDs) for 1160 sequelae of 289 diseases and injuries 1990-2010: a systematic analysis for the Global Burden of Disease Study 2010 / T. Vos, A. D. Flaxman, M. Naghavi [et al.] // Lancet. - 2012. - Vol. 380 (9859). P. 2163-2196.

6. COPD in never smokers: results from the populationbased burden of obstructive lung disease study / B. Lamprecht, M. A. McBurnie, W. M. Vollmer [et al.] // Chest. - 2011. Vol. 139 (4). - P. 752-763.

7. Хронічне обструктивне захворювання легені. Адаптована клінічна настанова, заснована на доказах : наказ Мiністерства охорони здоров' я України від 16.04.2014 № 2703 змінами [Електронний ресурс]. - Режим доступу : https://www. dec.gov.ua/wp-content/uploads/2019/11/2013 555 hozl kn.pdf.

8. Aryal S. Influence of sex on chronic obstructive pulmonary disease risk and treatment outcomes / S. Aryal, E. Diaz-Guzman, D. M. Mannino // Int. J. Chron. Obstruct. Pulmon. Dis. - 2014. - Vol. 9. - P. 1145-1154.

9. Gender differences in COPD: are women more susceptible to smoking effects than men? / I. C. Sorheim, A. Johannessen, A. Gulsvik [et al.] // Thorax. - 2010. - Vol. 65 (6). - P. 480-485.

10. Овчаренко С. И. Хроническая обструктивная болезнь легких: особенности у женщин / С. И. Овчаренко, В. А. Капустина // Пульмонология. - 2009. - № 2. DOI: https:// doi.org/10.18093/0869-0189-2009-2-102-112.

11. Архипов В. В. Заболевания легких при беременности / под ред. А. Г. Чучалина, В. И. Краснопольского, Р. С. Фассахова. - М. : Атмосфера, 2002. - 88 c.

12. Суховский В. С. Динамическая гипериноляция легких в период гестации / В. С. Суховский, Ф. Ф. Тетенев, В. В. Суховская // Пульмонология. - 2012. - № 2. - С. 25-29.

13. The etiologic origins for chronic obstructive pulmonary disease / X. Huang, X. Mu, L. Deng [et. al.] // Int. J. Chron. Obstruct. Pulmon. Dis. - 2019. - Vol. 14. - P. 1139-1158.

14. Respiratory function in pregnant women / L. Hirnle, L. Lysenko, H. Gerber [et. al.] // Adv. Exp. Med. Biol. - 2013. Vol. 788. - P. 153-160.

15. Влияние обострения хронического необструктивного и обструктивного бронхита вирусной этиологии у женщин во втором триместре беременности на состояние церебрального кровотока у их новорожденных / И. Н. Гориков, Л. Г. Нахамчен, Н. О. Косторомина, А. Г. Судаков // Бюл. сризиологии и патологии дыхания. - 2012. - Вып. 46. - С. 48-51.

16. Лаврова О. В. Влияние течения беременности и родов у женщин, страдающих бронхиальной астмой, на фрор- мирование этой патологии / О.В.Лаврова, Г.Б.Федосеева // Многоликая астма, диагностика, лечение и профилактика. - СПб., 2011. - С. 344.

17. Приходько О. Б. Адаптационные реакции у беременных с хроническими обструктивными заболеваниями органов дыхания / О. Б. Приходько, Е. Б. Романцова, А. Ф. Бабцева // Бюл. физиологии и патологии дыхания. 2007. - Вып. 24. - С. 66-68.

18. Wise R. A. Respiratory physiologic changes in pregnancy / R. A. Wise, A. J. Polito, V. Krishnan // Immunol. Allergy Clin. North Am. - 2006. - Vol. 26 (1). - P. 1-12.

19. Acute exacerbations of chronic obstructive pulmonary disease: identification of biologic clusters and their biomarkers / M. Bafadhel, S. McKenna, S. Terry [et al.] // Am. J. Respir. Crit. Care Med. - 2011. Vol. 184 (6). - P. 662-671.

20. Time course and pattern of COPD exacerbation onset / S. D. Aaron, G. C. Donaldson, G. A. Whitmore [et al.] // Thorax. - 2012. - Vol. 67 (3). - P. 238-243.

21. Авдеев С. Н. Значение обострений для пациентов с ХОБЛ / С. Н. Авдеев // Эффрективная фрармакотерапия. 2014. - № 2 (29). - С. 36-41.

22. Predominant $\mathrm{TH} 1$ cytokine pattern in peripheral blood from subjects with chronic obstructive pulmonary disease / M. Majori, M. Corradi, A. Caminati [et al.] // J. Allergy Clin. Immunol. - 1999. - Vol. 103 (3 Pt 1). - P. 458-462.

23. Борукаева И. Х. Особенности респираторной гипоксии у больных хронической обструктивной болезнью легких / И. Х. Борукаева // Успехи современного естествознания. 2007. - № 1. - C. 54-56.

24. Gillet S. Inflammation in COPD: pathogenesis, local and systemic effects / S. Gillet, C. A. Barbu, M. Poncelet // Rom. J. Morphol. Embryol. - 2011. - Vol. 52 (1). - P. 21-27.

25. Состояние фетоплацентарной системы при обострении хронического необструктивного и обструктивного бронхита у женщин в третьем триместре беременности / Л. Г. Нахамчен, И. Н. Гориков, В.Б.Приходько, И. Г. Квиткина // Бюл. фризиологии и патологии дыхания. - 2015. - Вып. 55. - С. 73-77.

26. Нахамчен Л. Г. Изменение местной специфической защиты и цитокинового статуса у женщин в I триместре беременности при обострении хронического бронхита, обусловленного вирусами респираторной группы / Л. Г. Нахамчен, И. Н. Гориков, Т. Е. Тальченкова // Бюл. фризиологии и патологии дыхания. - 2012. - Вып. 46. - С. 44-47.

27. Белан Э. Б. Бронхиальная астма и беременность / Э. Б. Белан, А. С. Кляусов // Лекарственный вестник. -2014. - T. 8, № 1 (53). - C. 8-17.

28. The Global Initiative for Asthma (GINA) 2016.

29. A meta-analysis of adverse perinatal outcomes in woman with asthma / V. E. Murphy, J. A. Namazy, H. Powell [et al.] // BJOG. - 2011. - Vol. 118 (11). - P. 1314-1323.

30. Management of asthma during pregnancy / D. J. Maselli, S. G. Adams, J. I. Peters, S. M. Levine // Ther. Adv. Respir. Dis. - 2013. - Vol. 7 (2). - P. 87-100.

31. Этиопатогенетические аспекты течения бронхиальной астмы во время гестации / А. Н. Рыбалка, 3. С. Румянцева, Е.Н.Лященко [и др.] // Журнал фундаментальной медицины и биологии. - 2015. - № 3. - С. 35-37. 
32. Влияние оксидативного стресса на микрососудистый эндотелий при бронхиальной астме / Л. П. Воронина, О. С. Полунина, И. В. Севостьянова [и др.] // Астраханский медицинский журнал. - 2013. - № 4, т. 8. - С. 54-57.

33. Clifton V. L. Increased anti-oxidant enzyme activity and biological oxidation in placentae of pregnancies complicated by maternal asthma / V. L. Clifton, J. Vanderlelie, A. V. Perkins // Placenta. - 2005. - Vol. 26 (10). - P. 773-779.

34. Placental cytokine expression covaries with maternal asthma severity and fetal sex / N. M. Scott, N. A. Hodyl, V. E. Murphy [et al.] // J. Immunol. - 2009. - Vol. 182 (3). - P. 1411-1420.

35. Вереина Н. К. Течение беременности и родов, состояние эндотелия у пациенток, куривших до беременности / Н. К. Вереина, В. С. Чулков // Журнал акушерства и женских болезней. - 2010. - T. LIX, вып. 3. - С. 110-113.

36. Иванова О. Ю. Состояние вазорегулирующей функции эндотелия при фризиологическом и осложненном течении беременности / О. Ю. Иванова, М. Г. Газязан, Н. А. Пономарева // Курский науч.-практ. вест. «Человек и его здоровье». - 2010. - № 4. - С. 68-72.

37. Ахминеева А. Х. Дисорункция эндотелия при хронической обструктивной болезни легких и бронхиальной астме / А. Х. Ахминеева, О. С. Полунина // Астраханский медицинский журнал. - 2012. - № 3, т. 7. - С. 43-46.

38. Furchgott R. The obligatory role of endothelial cells in the relaxation of arterial smooth muscle by acetylcholine / R. Furchgott, J. Zawadzki // Nature. - 1980. - Vol. 288 (5789) - P. 373-376.

39. Дорофриенко Н. Н. Роль сосудистого эндотелия в организме и универсальные механизмы изменения его активности (обзор литературы) / Н. Н. Дорофиенко // Бюл. фризиологии и патологии дыхания. - 2018. - Вып. 68. С. 107-116.

40. Burton G. J. Oxidative stress / G. J. Burton, E. Jauniaux // Best Pract. Res. Clin. Obstet. Gynaecol. - 2011. - Vol. 25 (3). - P. 287-299.

41. Oxidative stress: placenta function and dysfunction / F. Wu, F. J. Tian, Y. Lin, W. M. Xu // Am. J. Reprod. Immunol. 2016. - Vol. 76 (4). - P. 258-271.

42. Oxidative stress, placental ageing-related pathologies and adverse pregnancy outcomes / Z. Sultana, K. Maiti, J. Aitken [et al.] // Am. J. Reprod. Immunol. - 2017. - Vol. 77 (5). DOI: $10.1111 /$ aji.12653.

43. Oxidative stress markers in hypertensive states of pregnancy: preterm and term disease / L. O. Kurlak, A. Green, P. Loughna, F. Broughton Pipkin // Front. Physiol. - 2014. Vol. 5. - P. 310. DOI: 10.3389/fphys.2014.00310.

\section{REFERENCES}

1. (2017). Global Initiative for Chronic Obstructive Lung Disease (GOLD).

2. Blais, L., \& Forget, A. (2008). Asthma exacerbations during the first trimester of pregnancy and the risk of congenital malformations among asthmatic women. J. Allergy Clin. Immunol., 121 (6), 1379-1384. DOI: 10.1016/j.jaci.2008.02.038.

3. Burney, P.G., Patel, J., Newson, R., Minelli, C., \& Naghavi, M. (2015). Global and regional trends in COPD mortality, 1990-2010. Eur. Respir. J., 45 (5), 1239-1247. DOI: 10.1183/09031936.00142414.

4. Han, M.K., Postma, D., Mannino, D.M., Giardino, N.D., Buist, S., Curtis, J.L., \& Martinez, F.J. (2007). Gender and
44. Зверко В. Л. Недостаточное образование оксида азода как один из патогенетических фракторов угрозы невынашивания беременности / В. Л. Зверко, Н. Е. Максимович, Т. С. Милош // Журнал Гродн. гос. мед. ун-та. - 2010. - № 3. - С. 60-62.

45. Маркеры системного воспаления и эндотелиальной дисфункции у больных хронической обструктивной болезнью легких / М. Г. Мамаева, И. В. Демко, Я. И. Вериго [и др.] // Сибирское медицинское обозрение. - 2014. - № 1. - С. 12-16.

46. Serum levels of tumor necrosis factor- $\alpha$, interleukin-15 and interleukin-10 in patients with pre-eclampsia in comparison with normotensive pregnant women / F. Kalantar, S. Rajaei, A. B. Heidari [et al.] // Iran J. Nurs. Midwifery Res. - 2013. Vol. 18 (6). - P. 463-466.

47. Айламазян Э. К. Функциональная морфология плаценты человека в норме и при патологии (нейроиммуноэндокринологические аспекты) / Э. К. Айламазян, В. О. Полякова, И. М. Кветной. - СПб. : Изд-во Н-Л, 2012. -175 c.

48. Плацентарная недостаточность : учеб.-метод. пособие / Н. Г. Павлова, О. П. Аржанова, М. С. Зайнулина, А. В. Колобов ; под ред. Э. К. Айламазяна. - СПб. : ООО "Изд-во Н-Л", 2007. - 32 с.

49. Синопальников А. И. Внебольничная пневмония / А. И. Синопальников, О. В. Фесенко. - М. : ГЭОТАР-Медиа, 2017. -112 c.

50. Абулдинов А. С. Особенности течения внебольничной пневмонии у беременных : матер. XXI регион. науч.-практ. конф. «Молодежь XXI века: шаг в будущее» (Благовещенск, 20 мая 2020 г.). В 4 т. Т. 3. - Благовещенск : Изд-во Дальневост. гос. аграр. ун-та, 2020.

51. Risk of perinatal mortality associated with asthma during pregnancy: a 2-stage sampling cohort study / M. C. Breton, M. F. Beauchesne, C. Lemière [et al.] // Ann. Allergy Asthma Immunol. - 2010. - Vol. 105 (3). - P. 211-218.

52. Гориков И. Н. Состояние здоровья новорожденных от матерей с хроническим бронхитом вне обострения / И. Н. Гориков, Л. Г. Нахамчен, Н. О. Костромина // Бюл. фризиологии и патологии дыхания. - 2010. - № 37. - С. 53-55.

53. Interleukin-10 deficiency exacerbates toll-like receptor 3-induced preeclampsia-like symptoms in mice / P. Chatterjee, V. L. Chiasson, S. E. Kopriva [et al.] // Hypertension. - 2011. Vol. 58 (3). - P. 489-496.

54. Шиляева Е. Г. Клинико-морсологические особенности плацентарной недостаточности у беременных с бронхиальной астмой : автореф. дис. на соискание учёной степени канд. мед. наук : спец. : 14.01.01 / Екатерина Геннадиевна шиляева. - Казань, 2012. - 25 с.

chronic obstructive pulmonary disease: why it matters. Am. J. Respir. Crit. Care Med., 176 (12), 1179-1184. DOl: 10.1164/ rccm.200704-553CC.

5. Vos, T., Flaxman, A.D., Naghavi, M., Lozano, R., Michaud, C., Ezzati, M., ..., \& Memish, Z.A. (2012). Years lived with disability (YLDs) for 1160 sequelae of 289 diseases and injuries 1990-2010: a systematic analysis for the Global Burden of Disease Study 2010. Lancet, 380 (9859), 2163-2196. DOI: 10.1016/S0140-6736(12)61729-2.

6. Lamprecht, B., McBurnie, M.A., Vollmer, W.M., Gudmundsson, G., Welte, T., Nizankowska-Mogilnicka, E., ..., \& Buist, S.A. (2011). COPD in never smokers: results from the 
population-based burden of obstructive lung disease study. Chest, 139 (4), 752-763. DOI: 10.1378/chest.10-1253.

7. Khronichne obstruktyvne zakhvoriuvannia leheni. Adaptovana klinichna nastanova zasnovana na dokazakh (Zatverdzheno Nakazom Ministerstva okhorony zdorovia Ukrainy vid 16.04.2014 № 270 zi zminamy) [Chronic obstructive pulmonary disease. Adapted clinical guidelines based on evidence (approved by Order of the Ministry of Health of Ukraine dated April 16, 2014 No. 270 as amended)]. Retrieved from: https://www.dec.gov.ua/wp-content/uploads/2019/11/2013_555_ hozl_kn.pdf [in Ukrainian].

8. Aryal, S., Diaz-Guzman, E., \& Mannino, D.M. (2014). Influence of sex on chronic obstructive pulmonary disease risk and treatment outcomes. Int. J. Chron. Obstruct. Pulmon. Dis., 9, 1145-1154. DOI: 10.2147/COPD.S54476.

9. Sørheim, I.C., Johannessen, A., Gulsvik, A., Bakke, P.S. Silverman, E.K., \& DeMeo, D.L. (2010). Gender differences in COPD: are women more susceptible to smoking effects than men? Thorax, 65 (6), 480-485. DOI: 10.1136/thx.2009.122002.

10. Ovcharenko, S.I., \& Kapustina, V.A. (2009). Khronicheskaya obstruktivnaya bolezn legkikh: osobennosti u zhenshchin [Chronic obstructive pulmonary disease: particularities in women]. Pulmonologiya - Pulmonology, 2. DOI: https://doi.org/10.18093/08690189-2009-2-102-112 [in Russian].

11. Arkhipov, V.V. (2002). Zabolevaniya legkikh pri beremennosti [Lung diseases in pregnancy]. Chuchalin, A.G., Krasnopolskyy, V.I., \& Fassakhov, R.S. (Eds.). Moscow: Atmosfera [in Russian].

12. Sukhovsky, V.S., Tetenev, F.F., \& Sukhovskaya, V.V. (2012). Dinamicheskaya giperinflyatsiya legkikh v period gestatsii [Dynamic lung huperinflation in pregnancy]. Pulmonologiya - Pulmonology, 2, 25-29. DOI: https://doi.org/10.18093/08690189-2012-0-2-25-29.

13. Huang, X., Mu, X., Deng, L., Fu, A., Pu, E., Tang, T., \& Kong, $X$. (2019). The etiologic origins for chronic obstructive pulmonary disease. Int. J. Chron. Obstruct. Pulmon. Dis., 14, 1139-1158. DOI: 10.2147/COPD.S203215.

14. Hirnle, L., Lysenko, L., Gerber, H., Lesnik, P., Baranowska, A., Rachwalik, M., ..., \& Strozecki, L. (2013). Respiratory function in pregnant women. Adv. Exp. Med. Biol., 788, 153-160. DOI: 10.1007/978-94-007-6627-3 23.

15. Gorikov, I.N., Nakhamchen, L.G., Kostoromina, N.O., \& Sudakov, A.G. (2012). Vliyaniye obostreniya khronicheskogo neobstruktivnogo i obstruktivnogo bronkhita virusnoy etiologii u zhenshchin vo vtorom trimestre beremennosti na sostoyaniye tserebralnogo krovotoka u ikh novorozhdennykh [The Influence of the acute form of chronic non-obstructive and obstructive bronchitis of virus etiology in women in II trimester of pregnancy on the state of cerebral bloodflow in their newborns]. Byul. fiziologii i patologii dykhaniya - Bull. Physiology and Pathology of Respiration, 46, 48-51 [in Russian].

16. Lavrova, O.V., \& Fedoseyeva, G.B. (2011). Vliyaniye techeniya beremennosti i rodov u zhenshchin, stradayushchikh bronkhialnoy astmoy, na formirovaniye etoy patologii. Mnogolikaya astma, diagnostika, lecheniye i profilaktika [The influence of the course of pregnancy and childbirth in women suffering from bronchial asthma on the formation of this pathology. The many faces of asthma, diagnosis, treatment and prevention]. Saint-Petersburg [in Russian].

17. Prikhodko, O.B., Romantsova, Ye.B., \& Babtseva, A.F. (2007). Adaptatsionnyye reaktsii u beremennykh s khronicheskimi obstruktivnymi zabolevaniyami oragnov dykhaniya [Adaptive reactions in pregnant women with chronic obstructive diseases of respiratory organs]. Byul. fiziologii i patologii dykhaniya - Bull. Physiology and Pathology of Respiration, 24, 66-68 [in Russian].
18. Wise, R.A., Polito, A.J., \& Krishnan, V. (2006). Respiratory physiologic changes in pregnancy. Immunol. Allergy Clin. North Am., 26 (1), 1-12. DOI: 10.1016/j.iac.2005.10.004.

19. Bafadhel, M., McKenna, S., Terry, S., Mistry, V., Reid, C., Haldar, P., ..., \& Brightling, C.E. (2011). Acute exacerbations of chronic obstructive pulmonary disease: identification of biologic clusters and their biomarkers. Am. J. Respir. Crit. Care Med., 184 (6), 662-671. DOI: 10.1164/rccm.201104-0597OC.

20. Aaron, S.D., Donaldson, G.C., Whitmore, G.A., Hurst, J.R., Ramsay, T., \& Wedzicha, J.A. (2012). Time course and pattern of COPD exacerbation onset. Thorax, 67 (3), 238-243. DOI: 10.1136/thoraxjnl-2011-200768.

21. Avdeev, S.N. (2014). Znacheniye obostreniy dlya patsiyentov s KhOBL [Importance of relapses in COPD patients]. Effektivnaya farmakoterapiya - Effective Pharmacotherapy, 2 (29), 36-41 [in Russian].

22. Majori, M., Corradi, M., Caminati, A., Cacciani, G., Bertacco, S., \& Pesci, A. (1999). Predominant TH1 cytokine pattern in peripheral blood from subjects with chronic obstructive pulmonary disease. J. Allergy Clin. Immunol., 103 (3 Pt 1), 458462. DOI: 10.1016/s0091-6749(99)70471-9.

23. Borukayeva, I.Kh. (2007). Osobennosti respiratornoy gipoksii u bolnykh khronicheskoy obstruktivnoy boleznyu legkikh [Features of respiratory hypoxia in patients with chronic obstructive pulmonary disease]. Uspekhi sovremennogo yestestvoznaniya - Advances in Current Natural Sciences, 1, 54-56 [in Russian].

24. Gillet, S., Barbu, C.A., \& Poncelet, M. (2011). Inflammation in COPD: pathogenesis, local and systemic effects. Rom. J. Morphol. Embryol., 52 (1), 21-27.

25. Nakhamchen, L.G., Gorikov, I.N., Prikhodko, V.B., \& Kvitkina, I.G. (2015). Sostoyaniye fetoplatsentarnoy sistemy pri obostrenii khronicheskogo neobstruktivnogo i obstruktivnogo bronkhita $\mathrm{u}$ zhenshchin $\mathrm{v}$ tretyem trimestre beremennosti [The state of fetoplacental system at exacerbation of chronic nonobstructive and obstructive bronchitis in women in iii trimester of pregnancy]. Byul. fiziologii i patologii dykhaniya - Bull. Physiology and Pathology of Respiration, 55, 73-77 [in Russian].

26. Nakhamchen, L.G., Gorikov, I.N., \& Talchenkova, T.Ye. (2012). Izmeneniya mestnoy spetsificheskoy zashchity tsitokinovogo statusa $u$ zhenshchin $v 1$ trimestre beremennosti pri obostrenii khronicheskogo bronkhita obuslovlennogo virusami respiratornoy grup [Change of local specific protection and cytokine status in women in the first trimester of pregnancy at the acute form of chronic bronchitis conditioned by the viruses of respiratory group]. Byul. fiziologii i patologii dykhaniya - Bull. Physiology and Pathology of Respiration, 46, 44-47 [in Russian].

27. Belan, E.B., \& Klyausov, A.S. (2014). Bronkhialnaya astma i beremennost [Bronchial asthma and pregnancy]. Lekarstvennyy vestnik - Drug Bulletin, 8, 1 (53), 8-17 [in Russian].

28. (2016). The Global Initiative for Asthma (GINA).

29. Murphy, V.E., Namazy, J.A., Powell, H., Schatz, M., Chambers, C., Attia, J., \& Gibson, P.G. (2011). A meta-analysis of adverse perinatal outcomes in woman with asthma. BJOG, 118 (11), 1314-1323. DOI: 10.1111/j.1471-0528.2011.03055.x.

30. Maselli, D.J., Adams, S.G., Peters, J.I., \& Levine, S.M. (2013). Management of asthma during pregnancy. Ther. Adv. Respir. Dis., 7 (2), 87-100. DOI: 10.1177/1753465812464287.

31. Rybalka, A.N., Rumyantseva, Z.S., Lyashenko, H.N., Dizha, M.A., Gurskij, A.V. (2015). Etiopatogeneticheskiye aspekty techeniya bronkhialnoy astmy vo vremya gestatsii [Etiopathogenical aspects of bronchial asthma during gestation]. Zhurnal fundamentalnoy meditsiny i biologii - J. Fund. Med. Biol., 3, 35-37 [in Russian]. 
32. Voronina, L.P., Polunina, O.S., Sevostyanova, I.V., Kudryasheva, I.A., Kagin, A.V., \& Serdyukov, V.G. (2013). Vliyaniye oksidativnogo stressa na mikrososudistyy endoteliy pri bronkhialnoy astme [The influence of oxidative stress on endothelium of microvessels at bronchial asthma]. Astrakhanskiy meditsinskiy zhurnal - Astrakhan Medical Journal, 4, 8, 54-57 [in Russian].

33. Clifton, V.L., Vanderlelie, J., \& Perkins, A.V. (2005) Increased anti-oxidant enzyme activity and biological oxidation in placentae of pregnancies complicated by maternal asthma. Placenta, 26 (10), 773-779. DOI: 10.1016/j.placenta.2004.10.018.

34. Scott, N.M., Hodyl, N.A., Murphy, V.E., Osei-Kumah, A., Wyper, H., Hodgson, D.M., ..., \& Clifton, V.L. (2009). Placental cytokine expression covaries with maternal asthma severity and fetal sex. J. Immunol., 182 (3), 1411-1420. DOI: 10.4049/ jimmunol.182.3.1411.

35. Vereina, N.K., \& Chulkov, V.S. (2010). Techeniye beremennosti i rodov sostoyaniye endoteliya u patsiyentok kurivshikh do beremennosti [The course of pregnancy and childbirth, the state of the endothelium in female patients who smoked before pregnancy]. Zhurnal akusherstva i zhenskikh bolezney - Journal of Obstetrics and Women's Diseases, LIX, 3, 110-113 [in Russian].

36. Ivanova, O.Yu., Gazazyan, M.G., \& Ponomaryova, N.A (2010). Sostoyaniye vazoreguliruyushchey funktsii endoteliya pri fiziologicheskom i oslozhnennom techenii beremennost [Condition of vasoregulative function of endothelium in case of uncomplicated and complicated pregnancies]. Kurskiy nauch.prakt. vest. "Chelovek i yego zdorovye» - Kursk Scientific and Practical Bulletin "Man and His Health", 4, 68-72 [in Russian].

37. Ahmineeva, A.H., \& Polunina, O.S. (2012). Disfunktsiya endoteliya pri khronicheskoy obstruktivnoy bolezni legkikh i bronkhialnoy astme [The dysfunction of endothelium in chronic obstructive pulmonary disease and bronchial asthma]. Astrakhanskiy meditsinskiy zhurnal - Astrakhan Medical Journal, 3, 7, 43-46 [in Russian].

38. Furchgott, R., \& Zawadzki, J. (1980). The obligatory role of endothelial cells in the relaxation of arterial smooth muscle by acetylcholine. Nature, 288 (5789), 373-376. DOI: $10.1038 / 288373 a 0$.

39. Dorofienko, N.N. (2018). Rol sosudistogo endoteliya v organizme i universalnyye mekhanizmy izmeneniya yego aktivnosti (obzor literatury) [The role of vascular endothelium in the organism and the universal mechanisms of changing its activity (review)]. Byul. fiziologii i patologii dykhaniya - Bull. Physiology and Pathology of Respiration, 68, 107-116 [in Russian].

40. Burton, G.J., \& Jauniaux, E. (2011). Oxidative stress. Best Pract. Res. Clin. Obstet. Gynaecol., 25 (3), 287-299. DOI: 10.1016/j.bpobgyn.2010.10.016.

41. Wu, F., Tian, F.J., Lin, Y., \& Xu, W.M. (2016). Oxidative stress: placenta function and dysfunction. Am. J. Reprod. Immunol., 76 (4), 258-271. DOI: 10.1111/aji.12454.

42. Sultana, Z., Maiti, K., Aitken, J., Morris, J., Dedman, L., \& Smith, R. (2017). Oxidative stress, placental ageing-related pathologies and adverse pregnancy outcomes. Am. J. Reprod. Immunol., 77 (5). DOI: 10.1111/aji.12653.

43. Kurlak, L.O., Green, A., Loughna, P., \& Broughton Pipkin, F. (2014). Oxidative stress markers in hypertensive states of pregnancy: preterm and term disease. Front. Physiol., 5, 310. DOI: $10.3389 /$ fphys.2014.00310.
44. Zverko, V.L., Maksimovich, N.Ye., \& Milosh, T.S. (2010). Nedostatochnoye obrazovaniye oksida azota kak odin iz patogeneticheskikh faktorov ugrozy nevynashivaniya beremennosti [Insufficient formation of nitrogen oxide as one of the pathogenetic factors of the threat of miscarriage]. Zhurnal Grodnenskogo gosudarstvennogo meditsinskogo universiteta Journal of Grodno State Medical University, 3, 60-62 [in Russian].

45. Mamaeva, M.G., Demko, I.V., Verigo, Y.I., Kraposhina, A.Yu., Solovieva, I.A., \& Hendogina, V.T. (2014). Markery sistemnogo vospaleniya i endotelialnoy disfunktsii u bolnykh khronicheskoy obstruktivnoy boleznyu legkikh [Markers of systemic inflammation and endothelial dysfunction in patients with chronic obstructive pulmonary disease]. Sibirskoye meditsinskoye obozreniye Siberian Medical Review, 1, 12-16 [in Russian].

46. Kalantar, F., Rajaei, S., Heidari, A.B., Mansouri, R., Rashidi, N., Izad, M.H., \& Mirahmadian, M. (2013). Serum levels of tumor necrosis factor- $\alpha$, interleukin-15 and interleukin-10 in patients with pre-eclampsia in comparison with normotensive pregnant women. Iran J. Nurs. Midwifery Res., 18 (6), 463-466.

47. Aylamazyan, E.K., Polyakova, V.O., \& Kvetnoy, I.M. (2012). Funktsionalnaya morfologiya platsenty cheloveka $\checkmark$ norme i pri patologii (neyroimmunoendokrinologicheskiy e aspekty) [Functional morphology of the human placenta in health and disease (neuroimmunoendocrinological aspects)]. Saint-Petersburg: Izd-vo N-L [in Russian].

48. Pavlova, N.G., Arzhanova, O.N., Zaynulina, M.S., \& Kolobov, A.V. (2007). Platsentarnaya nedostatochnost: ucheb.-metod. posobiye [Placental insufficiency: study guide]. Aylamazyan, E.K. (Ed.). Saint-Petersburg: Izd-vo N-L [in Russian].

49. Sinopalnikov, A.I., \& Fesenko, O.V. (2017). Vnebolnichnaya pnevmoniya [Community-acquired pneumonia]. Moscow: GEOTAR-Media [in Russian].

50. Abuldinov, A.S. (2020). Osobennosti techeniya vnebolnichnoy pnevmonii u beremennykh [Features of the course of community-acquired pneumonia in pregnant women]. Proceedings of the $X X I$ regional Scientific and Practical Conference «Molodezh XXI veka: shag v budushcheye» - "Youth of the XXI century: a step into the future". Blagoveshchensk: Izdvo Dalnevost. gos. agrar. un-ta [in Russian]

51. Breton, M.C., Beauchesne, M.F., Lemière, C., Rey, E., Forget, A., \& Blais, L. (2010). Risk of perinatal mortality associated with asthma during pregnancy: a 2-stage sampling cohort study. Ann. Allergy Asthma Immunol., 105 (3), 211-218. DOI: 10.1016/j.anai.2010.06.021.

52. Gorikov, I.N., Nakhamchen, L.G., \& Kostromina, N.O. (2010). Sostoyaniye zdorovya novorozhdennykh ot materey $\mathrm{s}$ khronicheskim bronkhitom vne obostreniya [State of health of newborn from mothers with chronic bronchitis without exacerbation]. Byul. fiziologii i patologii dykhaniya - Bull. Physiology and Pathology of Respiration, 37, 53-55 [in Russian].

53. Chatterjee, P., Chiasson, V.L., Kopriva, S.E., Young, K.J., Chatterjee, V., Jones, K.A., \& Mitchell, B.M. (2011). Interleukin-10 deficiency exacerbates toll-like receptor 3-induced preeclampsia-like symptoms in mice. Hypertension, 58 (3), 489496. DOI: 10.1161/HYPERTENSIONAHA.111.172114.

54. Shilyayeva, E.G. (2012). Kliniko-morfologicheskiye osobennosti platsentarnoy nedostatochnosti u beremennykh $\mathrm{s}$ bronkhialnoy astmoy [Clinical and morphological features of placental insufficiency in pregnant women with bronchial asthma]. Candidate's thesis. Kazan [in Russian].

Отримано 08.04.21

Прийнято до друку 05.05.21

Електронна адреса для листування:oleksiakoi@tdmu.edu.ua 